\title{
pPeOp from Omphalia lapidescens Schroet induces cell cycle arrest and inhibits the migration of MC-4 gastric tumor cells
}

\author{
YONG-LE YANG, WEI-YAO GONG, FEI-FEI CHEN, LU-CHAO CHEN and YI-TAO CHEN \\ College of Life Sciences, Zhejiang Chinese Medical University, Hangzhou, Zhejiang 310053, P.R. China
}

Received September 12, 2015; Accepted January 19, 2017

DOI: $10.3892 / 01.2017 .6207$

\begin{abstract}
The aim of the present study was to investigate the effect of purified Omphalia lapidescens protein (pPeOp) extracted by polyvinylpyrrolidone from the fungus Omphalia lapidescens Schroet on the proliferation and cell cycle progression of MC-4 human gastric tumor cells. Using polyvinylpyrrolidone, $\mathrm{pPe} O \mathrm{p}$ was extracted from $O$. lapidescens Schroet. MC-4 cells were

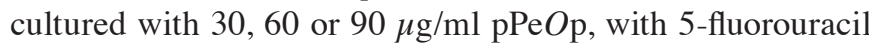
used as a positive control. Survival rates of treated cells were significantly decreased compared with those of the untreated control group in a dose-dependent manner. Using flow cytometric analysis, cells treated with $\mathrm{pPe} O \mathrm{p}$ were demonstrated to arrest in $S$ phase and exhibit abnormal $G_{0} / G_{1}$ and $G_{2} / M$ phase cell cycle distribution. In addition, a wound healing assay demonstrated that $\mathrm{pPe} O \mathrm{p}$ significantly inhibited the migration of MC-4 cells. The mRNA and protein expression levels of cyclin D1/cyclin-dependent kinase (CDK) 4, cyclin B/CDK1, cyclin A/CDK2, matrix metalloproteinase (MMP)-2 and MMP-9 were determined using reverse transcription-quantitative polymerase chain reaction analysis and western blotting. The mRNA expression level of CDK4 and cyclin A was significantly increased compared with the untreated control; however, cyclin D1, CDK1, CDK2, cyclin B, MMP-2, and MMP-9 exhibited a significantly decreased mRNA expression level, indicating that there is a negative association between concentration and cyclin D1 expression levels. The expression of the cycle arrest-associated proteins and migration-associated proteins examined were similar to the observed mRNA expression levels. In conclusion, $\mathrm{pPeO}$ p was identified to inhibit migration of and cause $\mathrm{S}$ phase cell cycle arrest in MC-4 cells.
\end{abstract}

\section{Introduction}

Gastric cancer is one of the most common gastrointestinal cancers worldwide, ranking second in terms of cancer-associated

Correspondence to: Dr Yi-Tao Chen, College of Life Sciences, Zhejiang Chinese Medical University, 548 Binwen Road, Hangzhou, Zhejiang 310053, P.R. China

E-mail: cytworld@163.com

Key words: Omphalia lapidescens proteins, gastric cancer, migration, cell cycle mortality rates $(1,2)$, and causing marked morbidity and mortality in China (3). Early detection is important in the treatment of this type of cancer, as advanced-stage diagnosis results in a poor prognosis $(4,5)$. Western medicine prioritizes surgical removal and other conventional treatment methods, which directly kill tumor cells or inhibit their proliferative and metastatic capabilities. However, these treatments cannot completely eliminate the tumor cells, and cause serious sideeffects in normal cells (5).

The treatment of tumors using traditional Chinese medicine has unique advantages (6,7). The use of traditional Chinese medicine in the treatment of cancer is able to significantly improve the quality of life and survival rate of patients (8). Omphalia lapidescens Schroet is widely used as a traditional anthelmintic in China. Previous studies have demonstrated that $O$. lapidescens Schroet effectively induces tumor necrosis; consequently, the China Food and Drug Administration has approved Lei Wan Pian and Lei Wan Jiao Nang as antitumor auxiliary drugs $(9,10)$. Research has revealed that the antitumor effects of the active ingredients from $O$. lapidescens Schroet are associated with certain polysaccharides and proteins (11-14), with mechanisms that include the direct killing of tumor cells through induction of apoptosis, and the enhancement of immune and anti-inflammatory responses. In a previous study (14), purified Omphalia lapidescens protein (pPeOp) was extracted from dried sclerotoids with polyvinylpyrrolidone (PVP) extraction buffer, and it was verified that a single protein band was retained following isolation of the major fraction using molecular-sieve chromatography. The major constituent, $\mathrm{pPe} O \mathrm{p}$, was identified with relatively high chromatographic purity. pPeOp increased apoptosis in human gastric tumor cells compared with conventional Western treatments, which induce tumor cell (MC-4 and SGC-7901) death and apoptosis significantly, but also trigger minor apoptosis of normal gastric cells (MC-1) (14). To further understand the underlying molecular mechanisms of the antitumor activities of $\mathrm{pPe} O \mathrm{p}$, its effects on tumor cell migration and cell cycle progression were investigated.

\section{Materials and methods}

Drugs and reagents. O. lapidescens Schroet powder was purchased from Fang Hui Chun Tang (Hangzhou, Zhejiang, China); the protein $\mathrm{pPe} O \mathrm{p}$ was extracted from dried sclerotoids of O. lapidescens Schroet using PVP extraction buffer [15\% 1.0 M Tris- $\mathrm{HCl}$ (pH 8.0), 2\% PVP and 25\% glycerol], 
Table I. Primers used in reverse transcription-quantitative polymerase chain reaction analysis.

\begin{tabular}{lll}
\hline Target & \multicolumn{1}{c}{ Forward primer $\left(5^{\prime}-3^{\prime}\right)$} & \multicolumn{1}{c}{ Reverse primer $\left(5^{\prime}-3^{\prime}\right)$} \\
\hline$\beta$-actin & ACCTGCAGCAATACCATTGAC & AAGGTGAGGGACTCAAACTGC \\
CDK1 & TGCTGGGGTCAGCTCGTTACTCA & TGGGATGCTAGGCTTCCTGGTT \\
CDK2 & GTGGGCCCGGCAAGATTTTAG & GCCGAAATCCGCTTGTTAGGG \\
CDK4 & CTTGATCTGAGAATGGCTACCTCT & CATGAAGGAAATCTAGGCCTCTTA \\
Cyclin D1 & CATCTCTGTACTTTGCTTGCTCAT & CGCTATTTCCTACACCTATTGGAC \\
Cyclin B & TCGAGCAACATACTTTGG & GCAAAAAGCTCCTGCTGC \\
Cyclin A & AGACCCTGCATTTGGCTGTG & ACAAACTCTGCTACTTCTGG \\
MMP-2 9 & TGATGGTGTCTGCTGGAAAG & GACACGTGAAAAGTGCCTTG \\
\hline
\end{tabular}

CDK, cyclin-dependent kinase; MMP, matrix metalloproteinase.

with $100 \mu \mathrm{g} / \mathrm{ml}$ 5-fluorouracil (5-FU) (Sigma-Aldrich; Merck KGaA, Darmstadt, Germany) as a positive control. Antibodies against cyclin-dependent kinase (CDK) 2 (cat. no. 2546T), cyclin B (cat. no. 4138T), CDK4 (cat. no. 12790T) and cyclin D1 (cat. no. 2922S) were purchased from Cell Signaling Technology, Inc. (Danvers, MA, USA). Antibodies against CDK1 (cat. no. ab131450), cyclin A (cat. no. ab181591), and MMP-2 (cat. no. ab37150) and -9 (cat. no. ab73734) were purchased from Abcam (Cambridge, UK). Anti- $\beta$-actin was used as a control and horseradish peroxidase (HRP)-conjugated goat anti-rabbit immunoglobulin $\mathrm{G}$ ( $\mathrm{IgG}$ ) was used as a secondary antibody. Both antibodies were purchased from Beyotime Institute of Biotechnology (Shanghai, China). Antibodies against CDK2, cyclin B, CDK4, cyclin D1, CDK1, MMP-2, MMP-9 and $\beta$-actin were diluted 1:1,000 in TBST containing $3 \%$ BSA, and antibody against cyclin A was diluted 1:2,000 for use.

Cell lines and cell culture. The human gastric cancer cell line MC-4 was obtained from the Zhejiang Provincial Center for Disease Control and Prevention (Hangzhou, China). MC-4 cells were cultured in RPMI-1640 medium (Genome Biotechnology, Hangzhou, China) supplemented with $10 \%$ (v/v) fetal bovine serum (Zhejiang Tianhang Biotechnology Co. Ltd. Hangzhou, China), 100 units $/ \mathrm{ml}$ penicillin and 100 units $/ \mathrm{ml}$ streptomycin (Genome Biotechnology) at $37^{\circ} \mathrm{C}$ in a humidified atmosphere containing 5\% $\mathrm{CO}_{2}$. Every 1-2 days, cells were used when $>80 \%$ cells were in the exponential growth phase. The control group was untreated MC-4 cells, MC-4 cells treated with $90 \mu \mathrm{g} / \mathrm{ml}$ PVP were used as a negative control and MC-4 cells treated with $100 \mu \mathrm{g} / \mathrm{ml} \mathrm{5-FU} \mathrm{were} \mathrm{used} \mathrm{as} \mathrm{a}$ positive control.

Cell counting kit (CCK)-8 assay. Exponential growth phase MC-4 cells were seeded in a 96-well plate at a density of $2 \times 10^{5}$ cells $/ \mathrm{ml} /$ well, and were placed in an incubator at $37^{\circ} \mathrm{C}$ overnight to allow for attachment and recovery. Cells were pretreated with $\mathrm{pPe} O \mathrm{p}(30,60$ or $90 \mu \mathrm{g} / \mathrm{ml}), 90 \mu \mathrm{g} / \mathrm{ml}$ PVP or $100 \mu \mathrm{g} / \mathrm{ml} 5$-FU (each drug was dissolved in RPMI-1640 medium), with 6 wells for each treatment and a total volume of $200 \mu \mathrm{l} /$ well. Following incubation at $37^{\circ} \mathrm{C}$ for $24 \mathrm{~h}$ in a humidified atmosphere containing $5 \% \mathrm{CO}_{2}, 20 \mu \mathrm{l}$ CCK-8 reagent was added to each well, prior to reincubating for $2 \mathrm{~h}$. The optical density of each well was measured at $490 \mathrm{~nm}$ using a multimode plate reader, with the viability of cells from three independent biological replicates calculated for each experiment.

Cell cycle analysis. Cells were quantified using a Cell Cycle and Apoptosis Analysis kit (cat. no. C1052; Beyotime Institute of Biotechnology), according to the manufacturer's protocol. MC- 4 cells were pretreated with pPeOp $(30,60$ or $90 \mu \mathrm{g} / \mathrm{ml})$, $90 \mu \mathrm{g} / \mathrm{ml} \mathrm{PVP}$ or $100 \mu \mathrm{g} / \mathrm{ml} 5$-FU prior to culturing at $37^{\circ} \mathrm{C}$ for $24 \mathrm{~h}$ in a humidified atmosphere containing $5 \% \mathrm{CO}_{2}$. The cells were subsequently washed with phosphate-buffered saline (PBS) three times and fixed with $70 \%$ ice-cold ethanol at $4^{\circ} \mathrm{C}$ overnight. The cells were centrifuged, washed with PBS, treated with $20 \mu \mathrm{l}$ RNase $\mathrm{A}$ in a water bath at $37^{\circ} \mathrm{C}$ for $30 \mathrm{~min}$, and placed in the dark at $4^{\circ} \mathrm{C}$ for 30 min with $300-500 \mu 1$ propidium iodide solution. The cell cycle distribution of the cells was determined using a Beckman FC500 flow cytometer (Beckman Coulter, Inc., Brea, CA, USA) with red fluorescent light at a wavelength of $488 \mathrm{~nm}$.

Wound healing assay. MC-4 cells at a density of $2 \times 10^{5}$ cells $/ \mathrm{ml}$ were seeded into 6 -well plates. The cells were cultured at $37^{\circ} \mathrm{C}$ in an atmosphere containing $5 \% \mathrm{CO}_{2}$ for $\sim 24 \mathrm{~h}$, at which time they were $\sim 80 \%$ confluent. Cells layers were scratched with a $200 \mu \mathrm{l}$ pipette tip. The cells were treated with 30 , 60 or $90 \mu \mathrm{g} / \mathrm{ml} \mathrm{pPeOp,} 90 \mu \mathrm{g} / \mathrm{ml}$ PVP, or $100 \mu \mathrm{g} / \mathrm{ml} 5-\mathrm{FU}$ and cultured at $37^{\circ} \mathrm{C}$ in a humidified atmosphere containing $5 \% \mathrm{CO}_{2}$ for $24 \mathrm{~h}$ to allow for migration into the cell-free area. Images of the cells were captured with a light microscope (magnification, $\mathrm{x} 40$ ) $24 \mathrm{~h}$ following treatment.

Reverse transcription-quantitative polymerase chain reaction $(R T-q P C R)$ analysis. Total RNA from the MC-4 cells treated with $\mathrm{pPe} O \mathrm{p}(30,60$ or $90 \mu \mathrm{g} / \mathrm{ml}), 90 \mu \mathrm{g} / \mathrm{ml} \mathrm{PVP}$ or $100 \mu \mathrm{g} / \mathrm{ml} 5$-FU was extracted using $\mathrm{TRIzol}^{\circledR}$ (Invitrogen; Thermo Fisher Scientific, Inc., Waltham, MA, USA), according to the manufacturer's protocol. cDNA was synthesized using a Maxima First Strand cDNA Synthesis kit (Thermo Fisher Scientific, Inc.), according to the manufacturer's protocol. The thermocycling conditions were as follows: $42^{\circ} \mathrm{C}$ for $60 \mathrm{~min}$ for the reverse transcription reaction; 


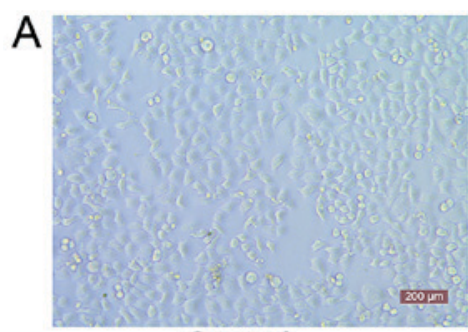

Control

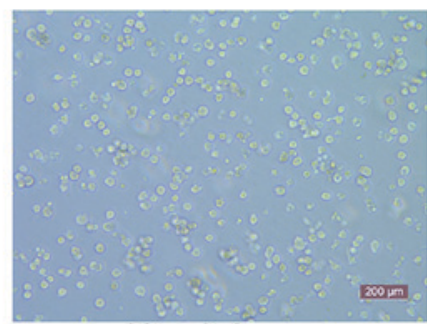

$30 \mu \mathrm{g} / \mathrm{ml}$

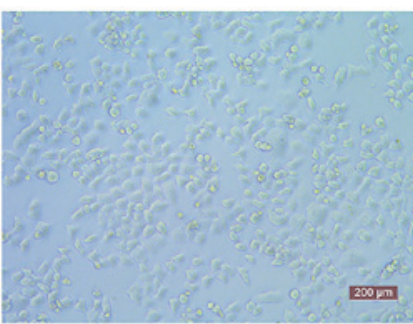

PVP

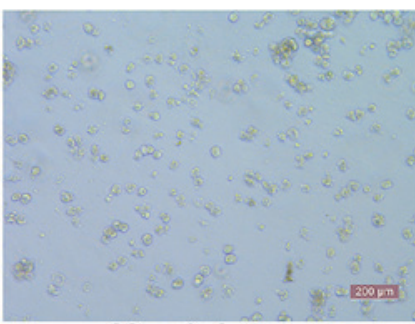

$60 \mu \mathrm{g} / \mathrm{ml}$

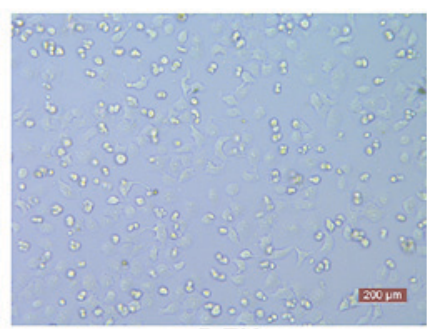

5-FU

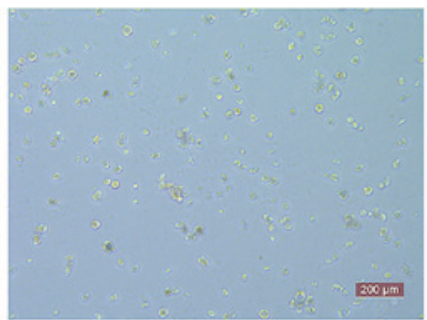

$90 \mu \mathrm{g} / \mathrm{ml}$

B

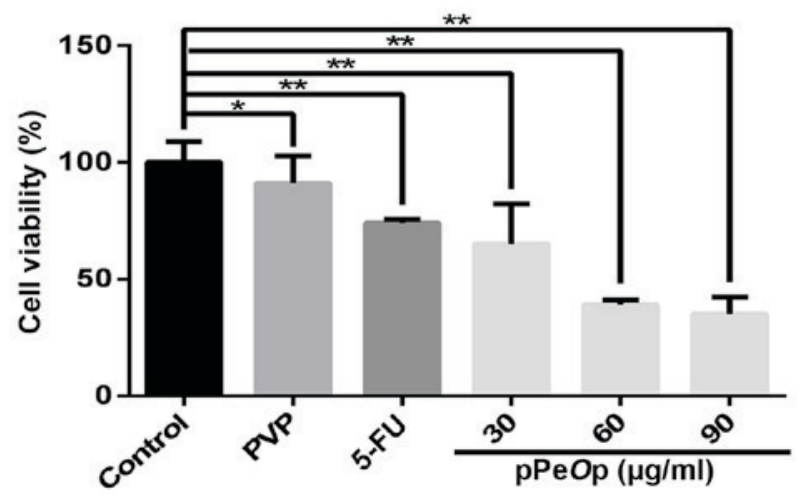

Figure 1. pPe $O$ p inhibits MC-4 cell proliferation. (A) MC-4 cells were treated with pPe $O \mathrm{p}$ (30, 60 or $90 \mu \mathrm{g} / \mathrm{ml}), 90 \mu \mathrm{g} / \mathrm{ml} \mathrm{PVP}$ (negative control) or $100 \mu \mathrm{g} / \mathrm{ml}$ 5-FU (positive control) for $24 \mathrm{~h}$, then visualized using light microscopy. In addition, untreated cells were used as the control group. (B) Cell viability rates were analyzed using a cell counting kit-8 assay following treatment. ${ }^{*} \mathrm{P}<0.05,{ }^{* *} \mathrm{P}<0.01$. pPeOp, purified Omphalia lapidescens protein; PVP, polyvinylpyrrolidone; 5-FU, 5-fluorouracil.

$70^{\circ} \mathrm{C}$ for $5 \mathrm{~min}$ to terminate the reaction; and finally immediate cooling on ice. The cDNA reaction solution was used as a template for subsequent qPCR. Primers used for qPCR are presented in Table I and were purchased from Sangon Biotech (Shanghai, China). qPCR was performed using a MasterCycler RealPlex ${ }^{4}$ Real-Time PCR instrument (Eppendorf, Hamburg, Germany). $\beta$-actin was used as an internal normalization control. The PCR amplification conditions using a two-step method were as follows: 1 cycle at $95^{\circ} \mathrm{C}$ for 2 min (pre-denaturing); 40 cycles of $95^{\circ} \mathrm{C}$ for $15 \mathrm{sec}$ (denaturing); and $62.9^{\circ} \mathrm{C}$ ( $\beta$-actin), $57.8^{\circ} \mathrm{C}$ (MMP2, MMP9, cyclin $\mathrm{A}$, cyclin $\mathrm{B}$, cyclin D1) or $61^{\circ} \mathrm{C}$ (CDK1, 2 and 4) for $1 \mathrm{~min}$ (annealing). At the end of the PCR cycle, a dissociation curve was created to confirm amplification of a single product. The results are represented as the fold change in gene expression relative to that of $\beta$-actin $\left(2^{-\Delta \Delta \mathrm{Cq}}\right)(15)$.

Western blotting. MC-4 cells were collected following treatment with $\mathrm{pPe} O \mathrm{p}(30,60$ or $90 \mu \mathrm{g} / \mathrm{ml}), 90 \mu \mathrm{g} / \mathrm{ml} \mathrm{PVP}$ or $100 \mu \mathrm{g} / \mathrm{ml} 5$-FU, subsequently lysed with radioimmunoprecipitation lysis buffer (Beyotime Institute of Biotechnology) for $30 \mathrm{~min}$ on ice. The lysates were separated by centrifugation at $12,000 \mathrm{x} \mathrm{g}$ for $15 \mathrm{~min}$ at $4^{\circ} \mathrm{C}$. The total protein concentration in the supernatants was determined using a bicinchoninic acid assay kit (Nanjing KeyGen Biotech Co., Ltd., Nangjing, China), according to the manufacturer's protocol. SDS-PAGE was performed using $10 \%$ gels with $\sim 20 \mu \mathrm{g}$ protein per lane. Proteins were subsequently transferred onto polyvinylidene fluoride membranes, which were blocked with 5\% dried skimmed milk in Tris-buffered saline containing $1 \%$ Tween-20 (TBST) and incubated with primary antibodies (described above) overnight at $4^{\circ} \mathrm{C}$. Membranes were washed three times with TBST and incubated with HRP-conjugated goat anti-rabbit $\operatorname{IgG}$ at room temperature for $2 \mathrm{~h}$, followed by washing three times with TBST. Images of the blots were captured on film in a darkroom using BeyoECL Plus Substrate kit (Beyotime Institute of Biotechnology) and were scanned and quantified using the Quantity One 1-D image analysis software (version 4.6.2; Bio-Rad Laboratories, Inc., Hercules, CA, USA).

Statistical analysis. All experiments were conducted in triplicate. Results are presented as the mean \pm standard error of the mean. Statistical analyses were performed using SPSS software for Windows (version 16.0; SPSS, Inc., Chicago, IL, USA). Statistical differences were assessed using the Student's t-test. $\mathrm{P}<0.05$ was considered to indicate a statistically significant difference. 


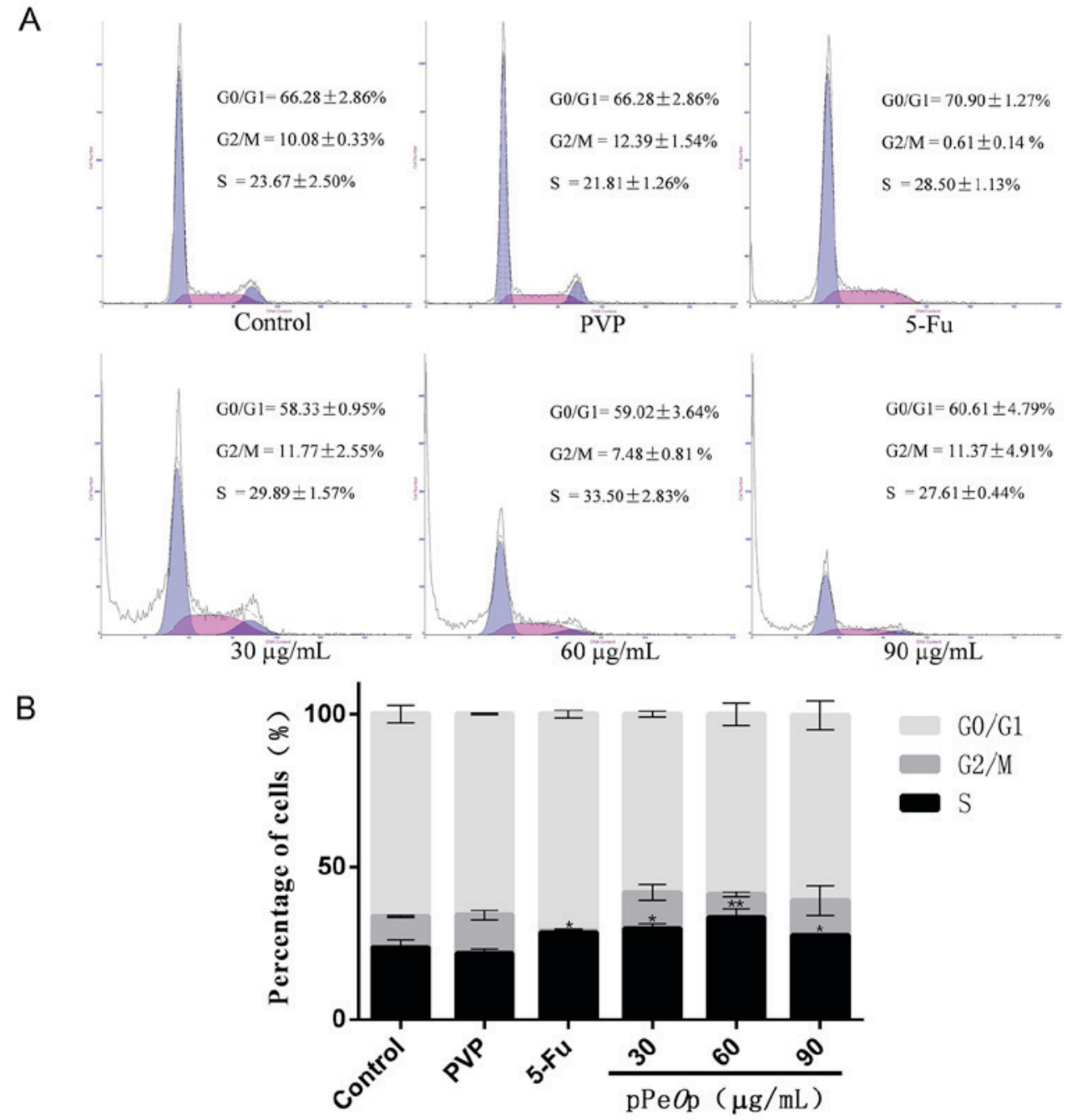

Figure 2. pPe $O \mathrm{p}$ arrests MC-4 cells in the S phase of the cell cycle. (A) MC-4 cells were treated with pPe $O \mathrm{p}(30,60 \mathrm{or} 90 \mu \mathrm{g} / \mathrm{ml}), 90 \mu \mathrm{g} / \mathrm{ml} \mathrm{PVP} \mathrm{(negative}$ control) or $100 \mu \mathrm{g} / \mathrm{ml} 5-\mathrm{FU}$ (positive control) for $24 \mathrm{~h}$, and analyzed using flow cytometry. In addition, untreated cells were used as the control group. (B) Summary graph of the cell cycle distribution of MC- 4 cells following treatment. Results are presented as the mean \pm standard deviation of $\geq 3$ independent experiments performed in triplicate. ${ }^{*} \mathrm{P}<0.05,{ }^{* *} \mathrm{P}<0.01$ vs. the untreated control group. pPeOp, purified Omphalia lapidescens protein; $\mathrm{PVP}$, polyvinylpyrrolidone; 5-FU, 5-fluorouracil.

\section{Results}

pPeOp inhibits MC-4 cell proliferation. As presented in Fig. 1A, cell proliferation was decreased in MC-4 cells $24 \mathrm{~h}$ following treatment with 30,60 or $90 \mu \mathrm{g} / \mathrm{ml} \mathrm{pPe} O \mathrm{p}$, and $100 \mu \mathrm{g} / \mathrm{ml} 5-\mathrm{FU}$ (positive control) compared with the untreated control group and $90 \mu \mathrm{g} / \mathrm{ml}$ PVP-treated cells (negative control). This decrease was significant for all concentrations of $\mathrm{pPe} O \mathrm{p}$ compared with the untreated control group $(\mathrm{P}<0.01$; Fig. 1B). As presented in Fig. 1B, the relative cell viability of each group was as follows: $30 \mu \mathrm{g} / \mathrm{ml}$ $\mathrm{pPe} O \mathrm{p}, 64.97 \pm 0.172 \% ; 60 \mu \mathrm{g} / \mathrm{ml}, 39.42 \pm 0.021 \% ; 90 \mu \mathrm{g} / \mathrm{ml}$, $35.23 \pm 0.074 \%$; PVP-treated negative control, $91.00 \pm 0.017 \%$; and 5-FU-treated positive control, $73.81 \pm 0.118 \%$. Compared with the 5-FU positive control group, an increase in $\mathrm{pPe} O \mathrm{p}$ concentration led to increased inhibition of proliferation in a dose-dependent manner.

pPeOp arrests the MC-4 cell cycle in $S$ phase. Treatment of MC-4 cells with various concentrations of $\mathrm{pPe} O \mathrm{p}$ led to alterations in cell cycle distribution following $24 \mathrm{~h}$, as presented in Fig. 2. Compared with the untreated control, following treatment with $\mathrm{pPe} O \mathrm{p}$ there was a significantly increased proportion of cells in $\mathrm{S}$ phase $(\mathrm{P}<0.05)$, but a decreased proportion of cells in $\mathrm{G}_{0} / \mathrm{G}_{1}$ phase (Fig. $2 \mathrm{~B}$ ). $\mathrm{pPe} O \mathrm{p}$ at a concentration of 30 and $90 \mu \mathrm{g} / \mathrm{ml}$ also increased the proportion of cells in $\mathrm{G}_{2} / \mathrm{M}$ phase compared with the untreated control, whereas $60 \mu \mathrm{g} / \mathrm{ml} \mathrm{pPeOp}$ decreased the proportion of cells in $\mathrm{G}_{2} / \mathrm{M}$ phase (Fig. 2B). In addition, compared with the 5 -FU-treated group, the proportion of cells in $\mathrm{S}$ phase in the 30

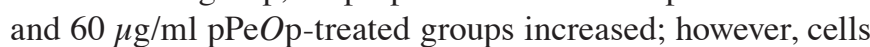
treated with $90 \mu \mathrm{g} / \mathrm{ml} \mathrm{pPeOp}$ exhibited a decreased proportion of cells in $\mathrm{S}$ phase. These results indicate that in $\mathrm{S}$ phase cell cycle arrest is induced by $\mathrm{pPe} O \mathrm{p}$.

$\mathrm{pPeOp}$ decreases cell migration. A wound healing assay was used to assess the role of $\mathrm{pPe} O \mathrm{p}$ in the migration of MC-4 cells. Microscopic analysis (Fig. 3) demonstrated that $\mathrm{pPe} O \mathrm{p}$ decreased the migratory rate of MC- 4 cells in a concentration-dependent manner, compared with the untreated control 


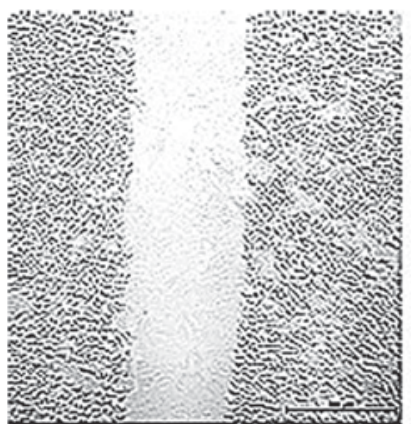

Control - $0 \mathrm{~h}$

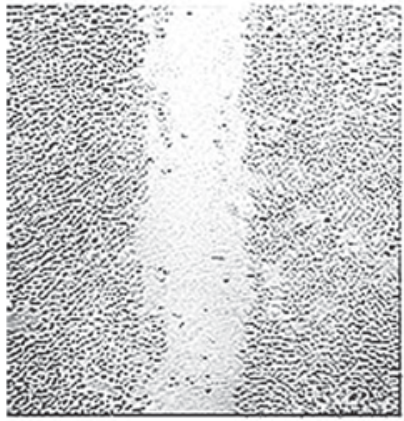

Control - $24 \mathrm{~h}$

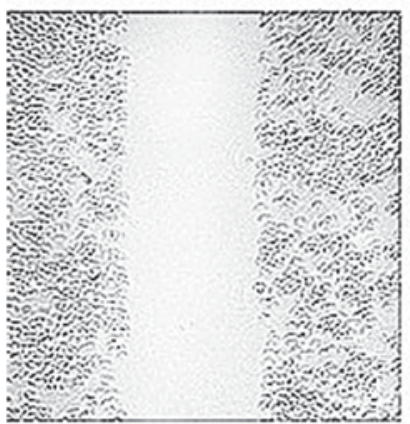

$30 \mu \mathrm{g} / \mathrm{ml}-0 \mathrm{~h}$

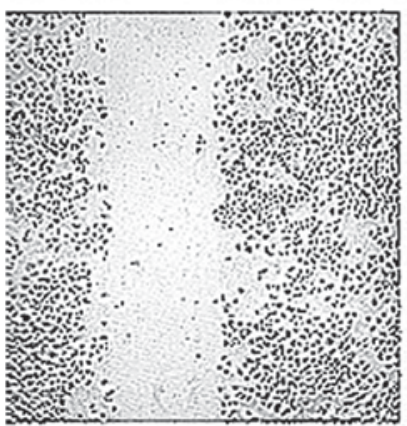

$30 \mu \mathrm{g} / \mathrm{ml}-24 \mathrm{~h}$

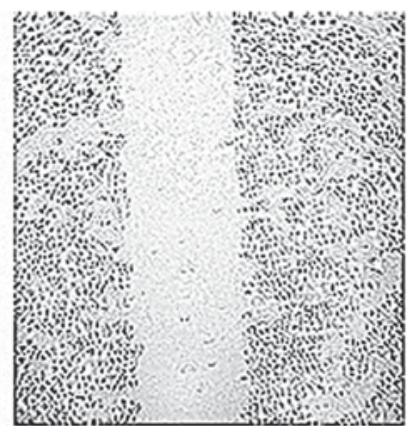

PVP - $0 \mathrm{~h}$



PVP - $24 \mathrm{~h}$

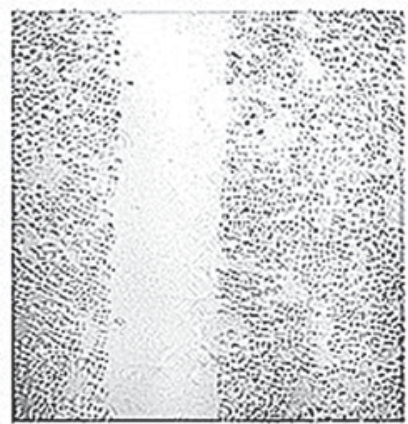

$60 \mu \mathrm{g} / \mathrm{ml}-0 \mathrm{~h}$

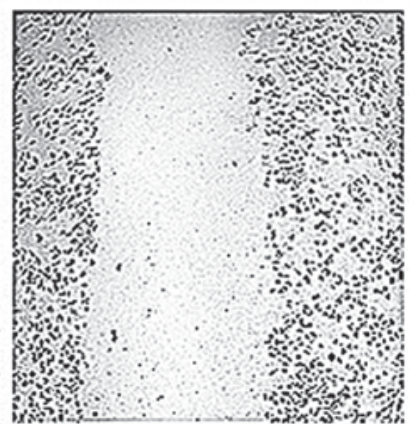

$60 \mu \mathrm{g} / \mathrm{ml}-24 \mathrm{~h}$

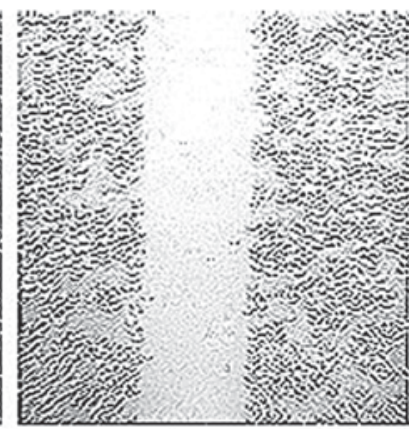

$5-\mathrm{FU}-0 \mathrm{~h}$

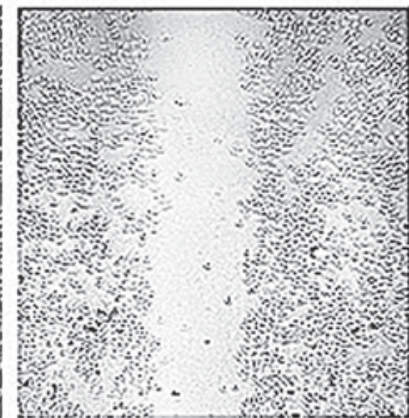

$5-\mathrm{FU}-24 \mathrm{~h}$

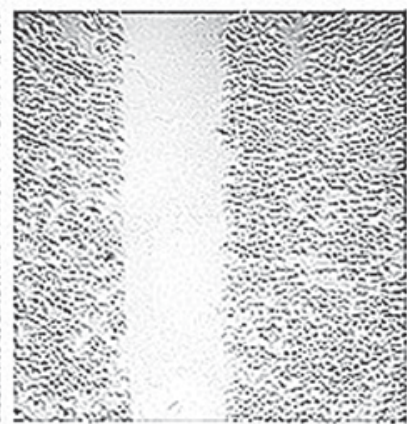

$90 \mu \mathrm{g} / \mathrm{ml}-0 \mathrm{~h}$

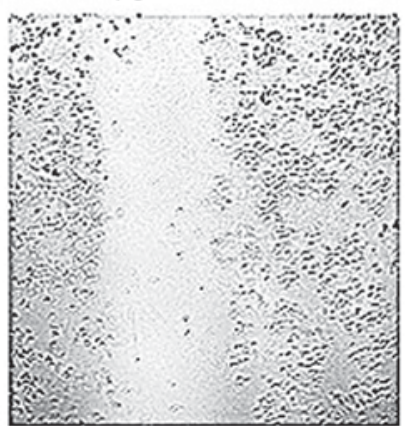

$90 \mu \mathrm{g} / \mathrm{ml}-24 \mathrm{~h}$

Figure 3. Effect of pPeOp on cell migration. Representative microscopic images of the wound healing assay demonstrating that in the untreated control and PVP-treated (negative control) groups there was no marked inhibition of migration. By contrast, treatment with 30,60 or $90 \mu \mathrm{g} / \mathrm{ml} \mathrm{pPe} O \mathrm{p}$ inhibited this migration in a concentration-dependent manner. Positive control consisted of treatment with $100 \mu \mathrm{g} / \mathrm{ml} 5$-FU. Magnification, x40. pPeOp, purified Omphalia lapidescens protein; PVP, polyvinylpyrrolidone; 5-FU, 5-fluorouracil.

cells. These results indicate that $\mathrm{pPe} O \mathrm{p}$ has a negative effect on MC-4 cell migration.

pPeOp affects the mRNA and protein expression of cell cycle- and migration-associated proteins in MC-4 cells. As presented in Fig. 4A, the mRNA expression levels of the cyclin B, cyclin D1, CDK1 and CDK2 were decreased in MC-4 cells treated with $\mathrm{pPe} O \mathrm{p}$ in a concentration-dependent manner compared with the untreated control group. However, the mRNA expression levels of cyclin A and CDK4 mRNA were increased compared with the untreated control in a concentration-dependent manner (Fig. 4A). In addition, the mRNA expression levels of cell migration-associated MMP2 and MMP9 in MC-4 cells were decreased significantly at all concentrations of $\mathrm{pPe} O \mathrm{p}$ used $(\mathrm{P}<0.001$; Fig. 4B). Furthermore, the expression of the cycle arrest-associated proteins cyclin D1, CDK4, cyclin B, CDK1, cyclin A and CDK2, and migration-associated proteins MMP-2 and MMP-9, were 


\section{A}
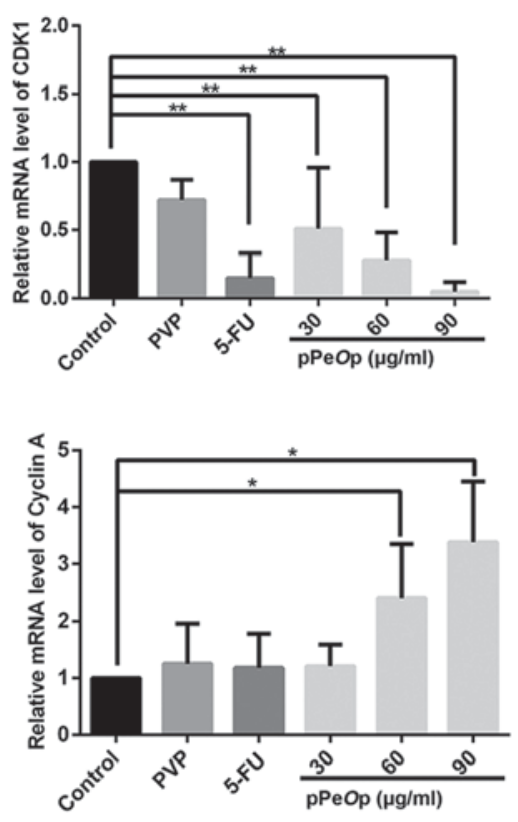

B

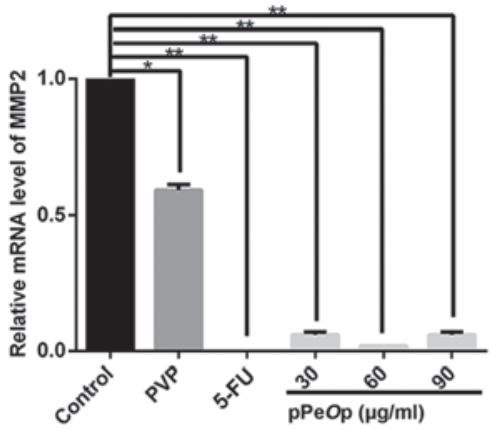

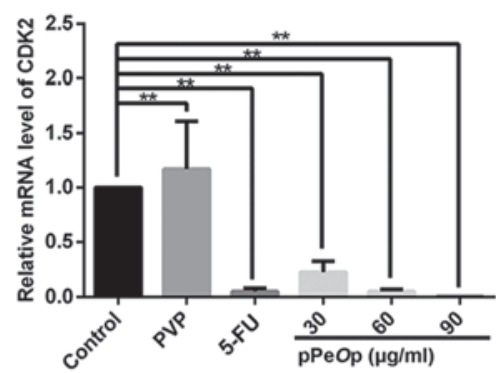
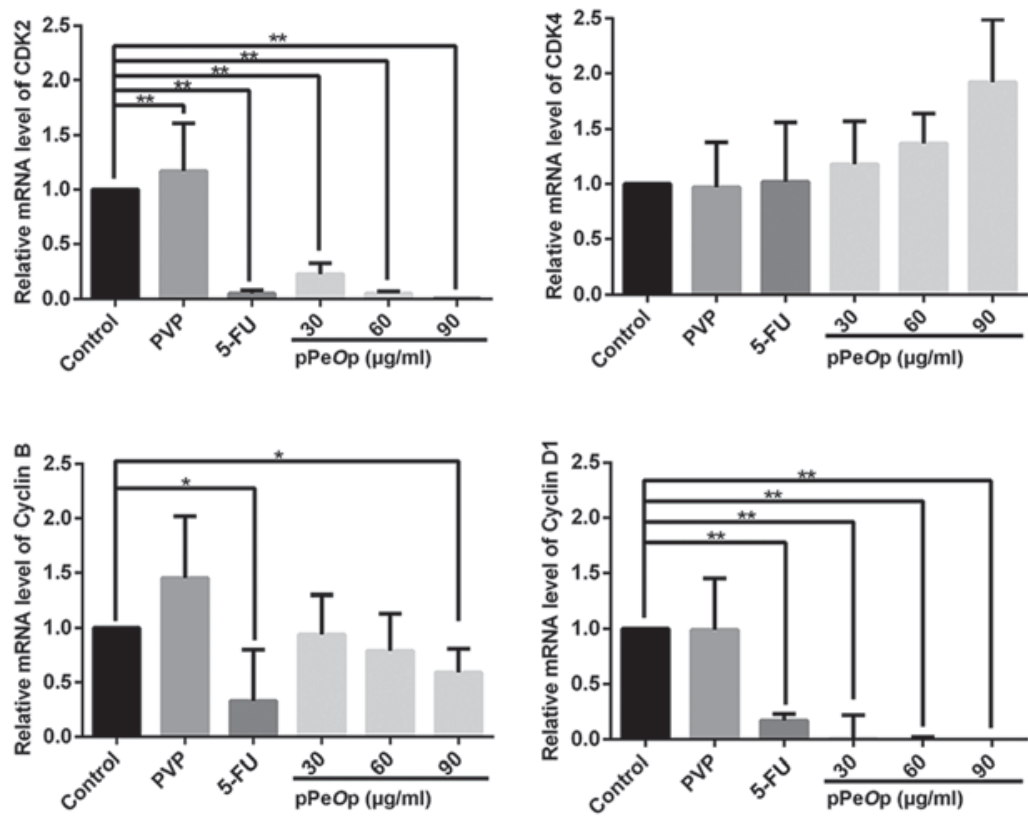

C Control PVP 5-FU $\frac{30 \quad 60 \quad 90}{\mathrm{pPeOp}(\mu \mathrm{\mu g} / \mathrm{ml})}$

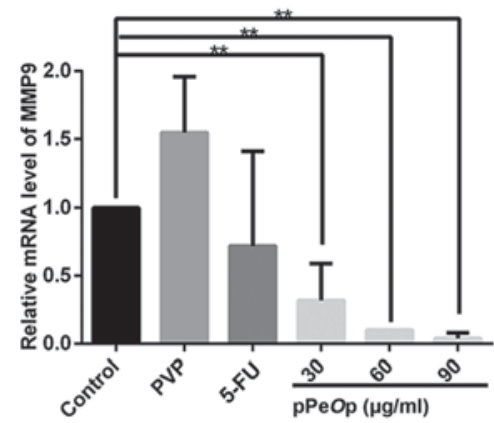

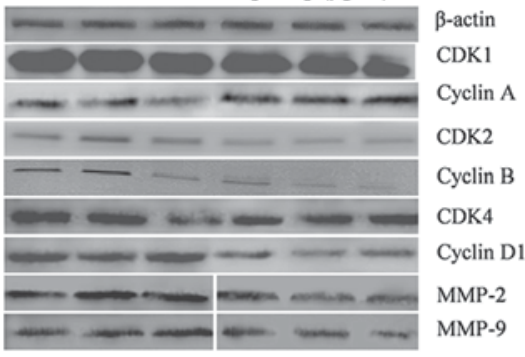

D
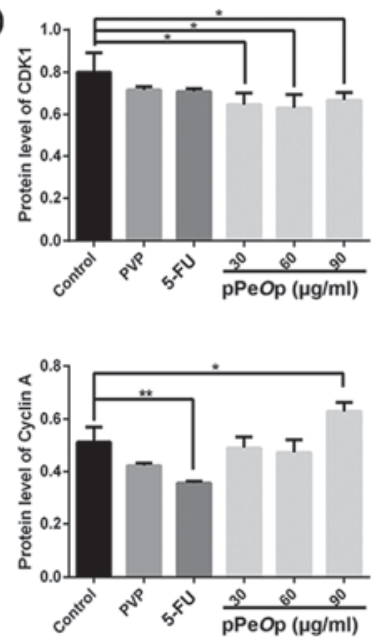
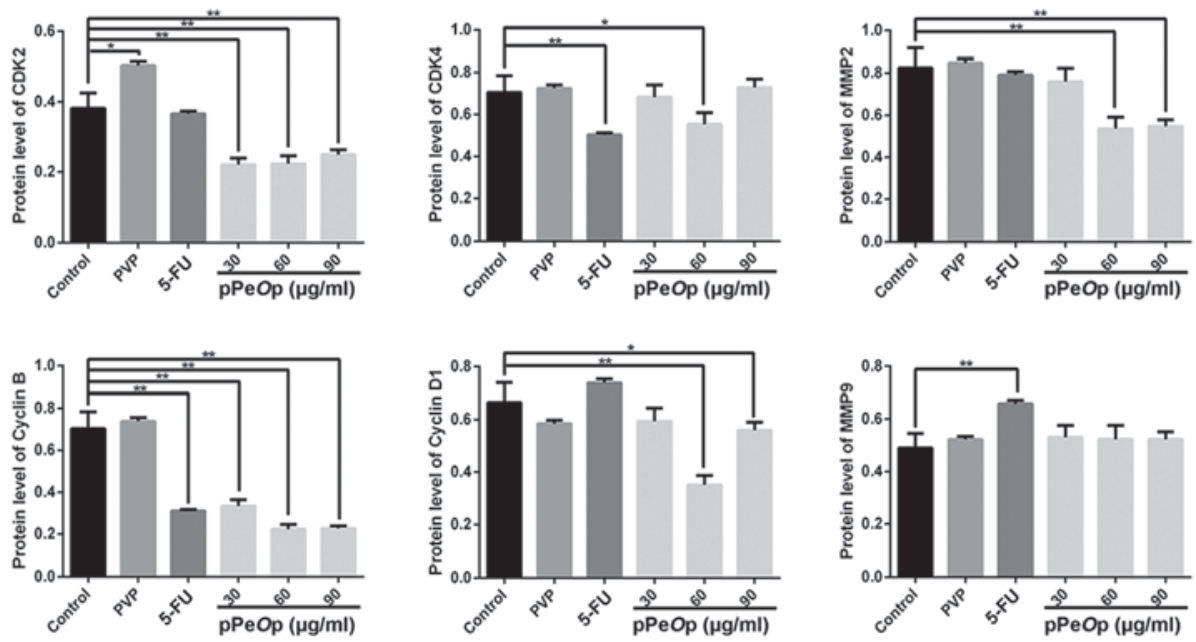

Figure 4. pPe $O \mathrm{p}$ affects the expression of cell cycle- and migration-associated genes/proteins in $\mathrm{MC}-4$ cells. Cells were treated with pPeOp (30, 60 or $90 \mu \mathrm{g} / \mathrm{ml}$ ), $90 \mu \mathrm{g} / \mathrm{ml}$ PVP (negative control) or $100 \mu \mathrm{g} / \mathrm{ml} \mathrm{5-FU} \mathrm{(positive} \mathrm{control)} \mathrm{for} 24 \mathrm{~h}$. In addition, untreated cells were used as the control group. Reverse transcription-quantitative polymerase chain reaction analysis was used to assess cell cycle-associated gene expression levels. All data were normalized to the untreated control. (A) Effects of pPeOp on the mRNA expression levels of the cell cycle-associated genes CDK1, CDK2, CDK4, cyclin A, cyclin B and cyclin D1. (B) Effects of pPeOp on the mRNA expression levels of the migration-associated genes MMP-2 and MMP-9. (C) Western blotting was conducted to examine the effects of $\mathrm{pPe} O \mathrm{p}$ on the expression of cell cycle- and migration-associated proteins, with $\beta$-actin used as a loading control. (D) Quantification of protein expression levels of cell cycle- and migration-associated proteins normalized to $\beta$-actin. ${ }^{*} \mathrm{P}<0.05$, ${ }^{* *} \mathrm{P}<0.01$. pPeOp, purified Omphalia lapidescens protein; PVP, polyvinylpyrrolidone; 5-FU, 5-fluorouracil; CDK, cyclin-dependent kinase; MMP, matrix metalloproteinase.

analyzed by western blotting, with similar results to their corresponding mRNA expression (Fig. 4C). Quantification of band density relative to that of $\beta$-actin demonstrated statistically significant differences in protein expression between 
the untreated control cells and cells treated with pPeOp, as presented in Fig. 4D.

\section{Discussion}

Migration, an important biological characteristic of cancer cells, is observed in gastric cancer $(16,17)$. The decreased survival rate of patients with gastric cancer may be attributed to the migration of gastric cancer cells into the lymph nodes and peritoneum $(18,19)$. MMP-2 and MMP-9 are the matrix metalloproteinases primarily involved in degradation of type IV collagen in the basement membrane, and are associated with malignant tumor infiltration and migration (20-22). MMPs are important regulatory molecules in tumor migration, and exhibit extensive and increased expression in various types of human malignant tumor (23). In tumorigenesis MMPs regulate the degradation of the ECM, regulate tumor angiogenesis, alter the function of cell adhesion molecules and mediate the proliferation of tumor cells (24). MMP-2 and MMP-9 may be biomarkers of the migratory ability of cancer cells (25-27).

An uncontrolled cell cycle is closely associated with tumor occurrence, development and malignancy $(28,29)$. Once cell proliferation or inappropriate cell death occurs, it typically results in a tumor, and it has been demonstrated that the regulation of the cell cycle is an important mechanism in tumorigenesis. Arrest of the various phases of the cell cycle may be used to inhibit cell proliferation and induce differentiation or apoptosis $(30,31)$. Cancer is a disease that causes disorders in the cell cycle and uncontrolled proliferation due to the combined effects of hereditary and environmental factors (32). Therefore, the exploration of the fundamental mode of tumor cell cycle regulation, examining the important issue of targeted drug therapy, has become central to research in the field of tumor-associated diseases.

The aim of studying the effects of the protein $\mathrm{pPe} O \mathrm{p}$ from $O$. lapidescens Schroet on the migration and cell cycle distribution of the human gastric cancer cell line MC-4 was to elucidate the underlying molecular mechanisms through which $\mathrm{pPeOp}$ functions. $\mathrm{pPe} O \mathrm{p}$ was demonstrated to significantly inhibit the proliferation of MC-4 cells; the proliferation of MC-4 cells was arrested in the $\mathrm{S}$ phase and led to abnormal distribution of $G_{1}$ and $G_{2}$ phase cells compared with the conventional chemotherapy drug 5-FU. Results from RT-qPCR analysis of the mRNA expression levels of cell cycle-associated genes and from the cell cycle analysis identified that $\mathrm{pPe} O \mathrm{p}$ induced upregulation of cyclin A and CDK4, which arrested cells in $\mathrm{S}$ phase. Previous studies have suggested that cyclins and CDKs are essential regulatory proteins in the cell cycle, and arrest of the cell cycle at the $G_{0} / G_{1}$ or $G_{2} / M$ phases is one of the mechanisms caused by anticancer therapies (33-35). The results of the present study demonstrated that $\mathrm{pPe} O \mathrm{p}$ is able to cause an abnormal $\mathrm{G}_{0} / \mathrm{G}_{1}$ and $\mathrm{G}_{2} / \mathrm{M}$ phase distribution of cells via downregulating the expression of cyclin D1, cyclin B, $\mathrm{CDK} 1$, and CDK2 genes in a concentration-dependent manner. In order to further clarify the role of $\mathrm{pPe} O \mathrm{p}$, the alteration in cell cycle-associated protein expression was examined, which revealed similar results to RT-qPCR analysis. Expression of cyclin B protein was notably downregulated and no marked expression was identified in the pPe $O$ p-treated cells, indicating that $\mathrm{pPeO}$ p induces $\mathrm{MC}-4$ cell apoptosis, which makes detection of the already low level of the corresponding expression of cyclin D1 difficult. Furthermore, the results of the wound healing assay demonstrated that $\mathrm{pPe} O \mathrm{p}$ decreased the migratory rate of MC-4 cells in a concentration-dependent manner. In addition, $\mathrm{pPe} O \mathrm{p}$ had a marked lethal effect on $\mathrm{MC}-4$ cells, which is consistent with Chen et al (14). However, the effect of $\mathrm{pPe} O \mathrm{p}$ on cell migration was not investigated by Chen et al. In the present study, $\mathrm{pPe} O \mathrm{p}$ induced apoptosis in the majority of the cells and induced cell migration. Additionally, the secretion of MMP-2 and MMP-9 decreased as shown by western blotting results. Cell migration was inhibited by the expression of MMP-2 and MMP-9. Concomitant with an increase in the concentration of $\mathrm{pPe} O \mathrm{p}$, the expression levels of MMP-2 and MMP-9 protein were decreased.

The downregulation of cyclin D1, cyclin B, CDK1 and $\mathrm{CDK} 2$, and upregulation of cyclin $\mathrm{A}$ and $\mathrm{CDK} 4$ by $\mathrm{pPe} O \mathrm{p}$ arrested MC-4 cells in the $\mathrm{S}$ phase of the cell cycle and led to an abnormal distribution of $\mathrm{G}_{0} / \mathrm{G}_{1}$ and $\mathrm{G}_{2} / \mathrm{M}$ phase cells. Furthermore, by downregulating MMP-2 and MMP-9 expression, $\mathrm{pPe} O \mathrm{p}$ inhibited the migration of $\mathrm{MC}-4$ cells. These results indicate that $\mathrm{pPe} O \mathrm{p}$ serves a role in cell cycle arrest and the inhibition of migration of $\mathrm{MC}-4$ gastric tumor cells. The identification and determination of the expression of other proteins that may be involved in the underlying molecular mechanism of action of $\mathrm{pPeOp}$ is warranted by further study.

\section{Acknowledgements}

The present study was supported by grants from the National Natural Science Foundation Project (grant no. 81374023), Zhejiang Provincial Natural Science Foundation (grant no. Y207765) and the Zhejiang Provincial Medical and Health Science and Technology Project (grant no. 2015106212).

\section{References}

1. Song W, Liu YY, Peng JJ, Liang HH, Chen HY, Chen JH, He WL, $\mathrm{Xu} \mathrm{JB}, \mathrm{Cai}$ SR and He YL: Identification of differentially expressed signatures of long non-coding RNAs associated with different metastatic potentials in gastric cancer. J Gastroenterol 51: 119-129, 2016.

2. Choi HJ, Ki CS, Suh SP and Kim JW: Presymptomatic identification of CDH1 germline mutation in a healthy Korean individual with family history of gastric cancer. Ann Lab Med 34: 386-389, 2014.

3. Jiang C, Chen X, Alattar M, Wei J and Liu H: MicroRNAs in tumorigenesis, metastasis, diagnosis and prognosis of gastric cancer. Cancer Gene Ther 22: 291-301, 2015.

4. Zhao J, Liu Y, Huang G, Cui P, Zhang W and Zhang Y: Long non-coding RNAs in gastric cancer: Versatile mechanisms and potential for clinical translation. Am J Cancer Res 5: 907-927, 2015.

5. Robertson-Tessi M, Gillies RJ, Gatenby RA and Anderson AR: Impact of metabolic heterogeneity on tumor growth, invasion, and treatment outcomes. Cancer Res 75: 1567-1579, 2015.

6. Li J, Li L, Liu R and Lin HS: Establishing Chinese medicine characteristic tumor response evaluation system is the key to promote internationalization of Chinese medicine oncology. Chin J Integr Med 18: 730-736, 2012.

7. Qi F, Li A, Inagaki Y, Gao J, Li J, Kokudo N, Li XK and Tang W: Chinese herbal medicines as adjuvant treatment during chemo- or radio-therapy for cancer. Biosci Trends 4: 297-307, 2010.

8. Ling CQ, Yue XQ and Ling C: Three advantages of using traditional Chinese medicine to prevent and treat tumor. J Integr Med 12: 331-335, 2014. 
9. Chen YT, Lin MA, Cheng DQ, Shi ZJ, Zhu JL and Wu J: Effect of proteins extracted from mycelia of Omphalia lapidescens on inhibiting $\mathrm{H}$, liver cancer in mice and regulating immune function. Zhong Yao Cai 32: 1870-1874, 2009 (In Chinese).

10. Yan H, Rong X, Chen PT, Zhang X and Ma ZQ: Two new steroids from sclerotia of the fungus Omphalia lapidescens. J Asian Nat Prod Res 16: 265-270, 2014.

11. Ohno N, Saito K, Nemoto J, Kaneko S, Adachi Y, Nishijima M, Miyazaki T and Yadomae T: Immunopharmacological characterization of a highly branched fungal (1->3)-beta-D-glucan, OL-2, isolated from Omphalia lapidescens. Biol Pharm Bull 16 414-419, 1993

12. Saito K, Nishijima M, Ohno N, Yadomae T and Miyazaki T: Structure and antitumor activity of the less-branched derivatives of an alkali-soluble glucan isolated from Omphalia lapidescens. (Studies on fungal polysaccharide. XXXVIII). Chem Pharm Bull (Tokyo) 40: 261-263, 1992.

13. Zhang G, Huang Y, Bian Y, Wong JH, Ng TB and Wang H: Hypoglycemic activity of the fungi Cordyceps militaris, Cordyceps sinensis, Tricholoma mongolicum, and Omphalia lapidescens in streptozotocin-induced diabetic rats. Appl Microbiol Biotechnol 72 1152-1156, 2006.

14. Chen YT, Lu QY, Lin MA, Cheng DQ, Ding ZS and Shan LT: A PVP-extract fungal protein of Omphalia lapidescens and its antitumor activity on human gastric tumors and normal cells Oncol Rep 26: 1519-1526, 2011.

15. Livak KJ and Schmittgen TD: Analysis of relative gene expression data using real-time quantitative PCR and the 2(-Delta Delta C(T)) method. Methods 25: 402-408, 2001

16. Zhang Y, Pan T, Zhong X and Cheng C: Androgen receptor promotes esophageal cancer cell migration and proliferation via matrix metalloproteinase 2. Tumour Biol 36: 5859-5864, 2015.

17. Lin Y, Peng N, Zhuang H, Zhang D, Wang Y and Hua ZC: Hea shock proteins HSP70 and MRJ cooperatively regulate cell adhesion and migration through urokinase receptor. BMC Cancer 14 639, 2014

18. Sun A, Yu G, Dou X, Yan X, Yang W and Lin Q: Nedd4-1 is an exceptional prognostic biomarker for gastric cardia adenocarcinoma and functionally associated with metastasis. Mol Cancer 13: 248, 2014.

19. Cao K, Xie D, Cao P, Zou Q, Lu C, Xiao S, Zhou J and Peng X: SiRNA-mediated flotillin-2 (Flot2) downregulation inhibits cell proliferation, migration, and invasion in gastric carcinoma cells Oncol Res 21: 271-279, 2014

20. Lu S, Zhu Q, Zhang Y, Song W, Wilson MJ and Liu P: Dual-functions of miR-373 and miR-520c by differently regulating the activities of MMP2 and MMP9. J Cell Physiol 230: 1862-1870, 2015.

21. Tong WW, Tong GH, Chen XX, Zheng HC and Wang YZ: HIF2o is associated with poor prognosis and affects the expression levels of survivin and cyclin D1 in gastric carcinoma. Int J Oncol 46: 233-242, 2015

22. Płuciennik E, Nowakowska M, Pospiech K, Stępień A, Wołkowicz M, Gałdyszyńska M, Popęda M, Wójcik-Krowiranda K, Bieńkiewicz A and Bednarek AK: The role of WWOX tumor suppressor gene in the regulation of EMT process via regulation of CDH1-ZEB1-VIM expression in endometrial cancer. Int J Oncol 46: 2639-2648, 2015 .
23. Leight JL, Tokuda EY, Jones CE, Lin AJ and Anseth KS: Multifunctional bioscaffolds for 3D culture of melanoma cells reveal increased MMP activity and migration with BRAF kinase inhibition. Proc Natl Acad Sci USA 112: 5366-5371, 2015.

24. Zheng L, Zhang YM, Zhan YZ and Liu CX: Momordica cochinchinensis seed extracts suppress migration and invasion of human breast cancer ZR-75-30 cells via down-regulating MMP-2 and MMP-9. Asian Pac J Cancer Prev 15: 1105-1110, 2014.

25. da Rosa MR, Falcão AS, Fuzii HT, da Silva Kataoka MS, Ribeiro AL, Boccardo E, de Siqueira AS, Jaeger RG, de Jesus Viana Pinheiro J and de Melo Alves Júnior S: EGFR signaling downstream of EGF regulates migration, invasion and MMP secretion of immortalized cells derived from human ameloblastoma. Tumour Biol 35: 11107-11120, 2014.

26. Liu F, Zhou J, Zhou P, Chen W and Guo F: The ubiquitin ligase CHIP inactivates NF- $\kappa \mathrm{B}$ signaling and impairs the ability of migration and invasion in gastric cancer cells. Int J Oncol 46: 2096-2106, 2015

27. Kim D, Lee D, Jang YL, Chae SY, Choi D, Jeong JH and Kim SH: Facial amphipathic deoxycholic acid-modified polyethyleneimine for efficient MMP-2 siRNA delivery in vascular smooth muscle cells. Eur J Pharm Biopharm 81: 14-23, 2012.

28. Matusewicz L, Meissner J, Toporkiewicz M and Sikorski AF: The effect of statins on cancer cells-review. Tumour Biol 36: 4889-4904, 2015.

29. Parajuli KR, Zhang Q, Liu S and You Z: Aminomethylphosphonic acid and methoxyacetic acid induce apoptosis in prostate cancer cells. Int J Mol Sci 16: 11750-11765, 2015.

30. Saiko P, Steinmann MT, Schuster H, Graser G, Bressler S, Giessrigl B, Lackner A, Grusch M, Krupitza G, Bago-Horvath Z, et al: Epigallocatechin gallate, ellagic acid, and rosmarinic acid perturb dNTP pools and inhibit de novo DNA synthesis and proliferation of human HL-60 promyelocytic leukemia cells: Synergism with arabinofuranosylcytosine. Phytomedicine 22: 213-222, 2015.

31. Hong S, Gu Y, Gao Z, Guo L, Guo W, Wu X, Shen Y, Sun Y, Wu X and Xu Q: EGFR inhibitor-driven endoplasmic reticulum stress-mediated injury on intestinal epithelial cells. Life Sci 119: 28-33, 2014.

32. Evers B, Helleday $\mathrm{T}$ and Jonkers J: Targeting homologous recombination repair defects in cancer. Trends Pharmacol Sci 31: 372-380, 2010.

33. Liu Z, Rader J, He S, Phung T and Thiele CJ: CASZ1 inhibits cell cycle progression in neuroblastoma by restoring $\mathrm{pRb}$ activity. Cell Cycle 12: 2210-2218, 2013

34. Cao Z, Lin W, Huang Z, Chen X, Zhao J, Zheng L, Ye H, Liu Z, Liao L and Du J: Ethyl acetate extraction from a Chinese herbal formula, Jiedu Xiaozheng Yin, inhibits the proliferation of hepatocellular carcinoma cells via induction of G0/G1 phase arrest in vivo and in vitro. Int J Oncol 42: 202-210, 2013.

35. Marconett CN, Morgenstern TJ, San Roman AK, Sundar SN, Singhal AK and Firestone GL: BZL101, a phytochemical extract from the Scutellaria barbata plant, disrupts proliferation of human breast and prostate cancer cells through distinct mechanisms dependent on the cancer cell phenotype. Cancer Biol Ther 10: 397-405, 2010 